\title{
ROUNDTABLE SESSION 1B
}

\section{CONTROL AND MANAGEMENT OF ALIEN CRAYFISH.}

\author{
P. SIBLEY (England), P. NÖEL (France)
}

\section{INTRODUCTION}

Indigenous or native crayfish populations have long been the subject of management in many regions of Europe, largely in the form of sustainable harvest for the table. Since the arrival and subsequent proliferation of non-indigenous or alien crayfish species, the need to control or manage their spread has been identified as a priority by fisheries managers and conservationists. In practice the development of broad-based and sitespecific strategies for this purpose should take place alongside a programme of research into the feasibility of controlling or even eradicating nuisance populations. Practical experience has been gained from the deployment of crayfish harvesting methods, and other potential control measures have been utilised. Progress in this field is subject to the familiar constraints of limited funding and finite resources but the experience gained from such work represents an important pool of information from which conservation agencies and researchers can formulate knowledge-based management decisions.

\section{ROUNDTABLE QUESTIONS}

It is perhaps testament to the relatively small amount of work currently being undertaken in this field in Europe that few questions were submitted for discussion prior to the session. Of approximately 40 workers from more than ten countries who were present at the roundtable, only two were actively involved in alien crayfish management.

The following questions were posed by the Chair, focusing in particular on the various control methods available for the management of alien crayfish populations (much of the discussion summarised below relied on field experience in the UK with Pacifastacus leniusculus).

1. Do we need to monitor crayfish distribution in order to undertake best management practice?

2. Should we bother attempting to control alien crayfish?

3. What control methods are currently available?

4. Has the spread of any invasive crayfish species been arrested or eradicated by large scale removals (or by any method)?

5. What impact have alien crayfish had on native flora and fauna?

6. Are there any examples of alien crayfish populations reaching a « natural balance » with the ecosystem into which they have been introduced. 
In addition the following questions were submitted to the Chair.

7. Is it possible to suppress an alien ( $P$. leniusculus) in the case of small streams (e.g. $2 \mathrm{~m}$ wide and $2 \mathrm{~km}$ long)? (B. FROMENT, France).

8. What chance do we have in small rivers and ponds? (ANON).

9. Is it an « utopy » to try and eradicate Orconectes limosus in ponds or streams? If yes, shouldn't we try to eradicate this species by introducing Pacifastacus, which is a species economically more interesting? (ANON).

\section{ANSWERS}

Due to limited time, questions 5, 6 and 9 were not specifically addressed during the session. Answers to 7 and 8 above were covered during group discussion of previous questions.

1. It was agreed that a programme of survey and subsequent distribution monitoring is essential for the formulation of management strategies. For potential control methods to be most effectively deployed the scale of the problem, in terms of population size and spread, must be determined.

2. The short answer to this question was « sometimes », depending on a range of factors. In practice there will be instances where it is unnecessary or impractical to attempt to control a particular alien crayfish population, e.g. in an area devoid of native species and already long occupied by alien crayfish. Conversely, there may be occasions where important populations of native crayfish (or other potentially vulnerable natural resources of high conservation value) are threatened by recently introduced aliens and the deployment of a suitable management practice would offer a reasonable chance of protecting the native species. However, in such an instance it was agreed that the eradication of an introduced population would be difficult to achieve, a more realistic goal being to control population growth.

3. A number of different control methods were discussed, as summarised below in alphabetical order.

\section{Biological Control (e.g. predators, disease)}

Predatory fish such as perch (Perca fluviatilis) or eel (Anguilla anguilla) could be stocked (at high density?) in waters containing alien crayfish in an attempt to regulate population growth. Introduced European catfish (Siluris glanis) had a marked effect on populations of Orconectes limosus in the River Saône in France (ARRIGNON et al., 1999). Stocking with predatory fish could have an adverse impact on other non-target prey species, but may be worth exploring in conjunction with other methods as a follow-up strategy. The pathogen Aphanomyces astaci is not effective against invasive species of North American origin although, with time and adequate funding, it might be possible to genetically modify it or other potentially useful organisms (e.g. Bacillus thuringiensis).

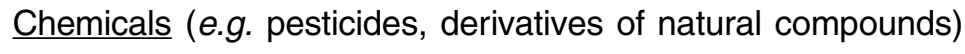

HOLDICH et al. (1999) reviewed the experimental work undertaken to determine the toxicity of certain chemicals to alien crayfish species, and mass mortalities have been reported following accidental or negligent chemical spills (e.g. sheep dip). The use of 
pesticides as a control method was thought to be generally unacceptable since none is specific to astacids and the likely impact on « non-target » organisms would be high. However, there could be circumstances, such as with isolated waters of low conservation value, where their use, if permitted by law, might be advantageous. Natural derivatives such as Tea Seed Cake (used in the commercial husbandry of shrimp) could have some value as control agents but would need further investigation.

\section{Chemical Barriers (i.e. pollution)}

The observation was made that poor water quality has prevented the general expansion of range of alien crayfish in some European countries, and reaches of poor quality in specific rivers have had a similar effect elsewhere. Clearly, the use of polluting discharges as a control measure would have an adverse impact on the wider environment and could be prohibited by legislation.

\section{Crayfish Fishing}

It was suggested that fishery managers could facilitate easy, perhaps signposted public access to alien crayfish waters in order to encourage their removal (e.g. by lift traps) for consumption. Could have limited or «PR » value in « crayfish consuming countries », but there are potential problems including the risk of spreading crayfish plague.

\section{Draining Down}

Where practical to do so, this could allow the collection of « stranded » crayfish, but the process would clearly impact upon other aquatic organisms. Quick and complete control is unlikely since some species are known to have survived for months in damp burrows and refuges (HOLDICH et al., 1999).

\section{Electric Fishing} option.

All agreed this was a useful survey method, but would be of limited use as a control

\section{Electrical Barriers}

It is possible that this method could be effective in preventing crayfish from entering a pipe or tributary, etc., but high cost installation and practical constraints would be likely to render it unrealistic.

Legislation (e.g. banning introductions, use as livebait, etc.)

This topic was the subject of roundtable discussion $2 \mathrm{~A}$.

Manual (e.g. hand searching, netting)

Resource implications may be prohibitive since large numbers of workers are required to search or hand-net efficiently. Seine nets can be used to good effect in shallow waters where they can be dragged across a snag-free substrate, and fine mesh nets do allow the capture of juvenile crayfish $<1 \mathrm{~cm}$ carapace length. Hand-nets have been used with some success by teams of workers in a small 1-2 $\mathrm{m}$ wide river in England where the method is well suited to the soft clay substrate (e.g. One session netted 3500 signal crayfish from a $500 \mathrm{~m}$ length at the expense of 60 « man days » of effort (SIBLEY, 2001a)). This method may be hindered by the inclination of $P$. leniusculus to excavate and shelter in burrows (although repeat nettings carried out in quick succession often yielded higher catches than the initial " sweep »). 
Mechanical (e.g. traps)

Traps have long been used to catch crayfish, though historically the practice was employed on a sustainable basis, not intended to diminish production. However, trapping can be a highly effective management tool, well suited to deep stillwaters, and will regulate crayfish populations if carried out on a large enough scale. Trapping is selective for mature active animals and will also yield a disproportionate number of males (BROWN and BREWIS, 1978). To reduce productivity a rolling programme of sustained trapping would be necessary and this would be unlikely to eliminate crayfish since the method is unsuited to the capture of juveniles.

\section{Pheromones}

The potential use of chemical signals for the control of non-indigenous crayfish is currently the subject of a research project at the University of Newcastle in England (STEBBING et al., 2001). Behavioural bioassay techniques are being developed to monitor conspecific responses to pheromonal signals with a view to exploiting such chemicals as attractants and/or repellents. These could clearly be of use in, for example, increasing trap efficiency or deterring range expansion.

\section{Physical Barriers (e.g. waterfalls, weirs, etc.)}

Natural barriers can impede or even prevent invasive crayfish from expanding their range and reduce the spread of disease. The creation of man-made barriers (e.g. specially adapted outflow pipes from stillwaters (STUCKI, 2001)) could do likewise in some situations. The method would be ineffective against species able to walk around such a barrier (e.g. Procambarus clarkii)!

\section{$\underline{\text { Sex Ratio Manipulation }}$}

The selective removal of female (and juvenile) crayfish may serve to reduce population growth directly by lowering egg production. It is also known that large adult males of certain species will predate juveniles and suppress their daily activity (MOMOT, 1993), hence leaving these animals in situ could exert a form of intra-specific regulation. However, in line with studies on other invertebrates (BEGON et al., 1990) a recent project in the UK with $P$. leniusculus suggested that lowering the population density (of mature females) led to an increase in recruitment the following year (SIBLEY, 2001b). This factor (i.e. density dependent fecundity) could negate the impact of selective removals, or for that matter any short or medium term control measures.

\section{$\underline{\text { Sterilisation }}$}

The capture, sterilisation and release of large numbers of male crayfish was suggested as a potential method of reducing fecundity and growth in any given population. A considerable and sustained effort would almost certainly be necessary to ensure that a high enough proportion of resident male crayfish were sterilised. Further study would be needed to identify a suitable sterilisation technique.

4. Sustained programmes of trapping have been successful in reducing population growth in relatively small stillwaters. This technique has not been found to eradicate crayfish, and has been utilised less successfully in running waters. A suite of methods were examined during a recent research project in the UK, which examined case studies from still and running waters, but none have resulted in the successful elimination of target crayfish populations (ENVIRONMENT AGENCY, 1998 start). 


\section{CONCLUSIONS}

An interesting discussion was held, in particular relating to question 3 which yielded an extensive list of potential control methods. Several speakers stressed the importance of further research in this field (e.g. regarding the development of pheromones, sterilisation and the use of biological control agents).

Two additional subjects were raised during this discussion about future work.

Firstly, the observation was made by P. NÖEL that crayfish appear to be more sensitive to pollutants during the moult period. It was suggested that timing a "low volume » chemical treatment to coincide with the moult period could selectively eliminate crayfish while leaving other aquatic organisms unharmed. Here there is a need for further research.

Secondly, the phenomenon of stunted crayfish populations was raised in relation to work undertaken by L. EDSMAN. It was reported that occasional « dwarf » populations of indigenous and non-indigenous species are found in some Swedish Lakes (L. EDSMAN, pers. comm.). Early hypotheses suggested that slow growth as a result of high density and intense food competition was responsible for stunted growth, or that some unknown abiotic factor dictated against " normal » growth. However, research has identified the same growth rates in stunted and normal populations, the difference being that « dwarf » crayfish in fact have a shorter life span. The explanation for this is as yet unknown, and there are clearly repercussions in terms of management policy relating to exploitation. Identification of the factor(s) causing shortened life span and stunted growth could also be of considerable use in relation to the control of unwanted alien populations.

The roundtable session emphasised the benefit to be derived from the exchange of information, and it is important that experience gained during attempts to control alien crayfish is made widely available, whether as formal published work or through « informal » media such as by e-mail, internet or newsletter.

Control and management of aliens is clearly desirable where the survival of native crayfish populations are threatened. Management strategies should be formulated on a site by site basis, prioritising those most in need of action, and where this is deemed necessary a selection of the most appropriate methods should be deployed.

\section{REFERENCES}

ARRIGNON J.C.V., GÉRARD P., KRIER A., LAURENT P.J., 1999. Case studies of alien crayfish in Europe. The situation in Belgium, France and Luxembourg. In : Crayfish in Europe as alien species - how to make the best of a bad situation?, 129-140. (GHERARDI F. and HOLDICH D.M., Eds.). Crustacean Issues 11. Balkema, Rotterdam.

BEGON M., HARPER J.L., TOWNSEND C.R., 1990. Ecology: Individuals, Populations and Communities. Blackwell, Boston, $945 \mathrm{p}$.

BROWN D.J., BREWIS J.M., 1978. A critical look at trapping as a method of sampling a population of Austropotamobius pallipes (Lereboullet) in a mark and recapture study. Freshwater Crayfish, 4, 159-164.

ENVIRONMENT AGENCY, 1998 start. R\&D project, Eradication of alien crayfish populations. Environment Agency / English Nature.

HOLDICH D.M., GYDEMO R., ROGERS W.D., 1999. A review of possible methods for controlling alien crayfish populations. In : Crayfish in Europe as alien species - how to make the best of a bad situation?, 245-270. (GHERARDI F. and HOLDICH D.M., Eds.). Crustacean Issues 11. Balkema, Rotterdam. 
MOMOT W.T., 1993. The role of exploitation in altering the processes regulating crayfish populations. Freshwater crayfish, 11, 101-117.

SIBLEY P.J., 2001a. Signal crayfish management in the River Wreake catchment. In : ROGERS D. and BRICKLAND J. (Eds.), Crayfish Conference Leeds (2000), 95-107. Environment Agency / International association of Astacology / English Nature.

SIBLEY P.J., 2001b. Signal crayfish, Pacifastacus leniusculus (Dana), in the Gaddesby Brook, Leicestershire. Population assessment and management options. Report for the Environment Agency carried out in fulfilment of the requirement of the IFM Diploma, $28 \mathrm{p}$.

STEBBING P., WATSON G., BENTLEY M., FRASER D., JENNINGS R., RUSHTON S., SIBLEY P., 2001. The potential use of chemical signals for the control of non-native species of crayfish in the British Isles. Knowledge-based management of European native crayfishes, Poitiers, France, September 13-15, 2001. Abstracts, p. 39.

STUCKI T.P., 2001. Management of two populations of American crayfish species in Switzerland. Knowledge-based management of European native crayfishes, Poitiers, France, September 13-15, 2001. Abstracts, p. 24. 